\title{
Tål andres smerte 器
}

\author{
Feriestart med båt og familie tok en brå vending fredag 22. juli. Via radio får jeg høre at hele Regjerings- \\ kvartalet er bombet. Jeg drar hjem og slår på TV-en. Kort tid etter kommer informasjon om skyting på Utøya. \\ Politiet anmoder om kriseteam i beredskap.
}

Som faglig leder av kriseteamet i Tønsberg kommune besluttet jeg å sammenkalle kriseteamet lørdag formiddag. Vårt nye kriseteam ble etablert våren 2011, så planene våre var rykende ferske.

Administrativ leder og jeg fordelte arbeidsoppgaver. Vi varslet kommuneledelsen og fylkeslegen. Jeg kontaktet Vestfold Arbeiderparti og drøftet ulike scenarier. De ønsket at kriseteamet i Tønsberg skulle fungere for hele Vestfold Arbeiderparti. Jeg valgte å bruke Facebook til enkelte oppdateringer.

\section{Facebook natt til lørdag}

Vårt psykososiale kriseteam er i beredskap og samles i morgen. Flere er ventet tilbake fra Utøya/Sundvolden. Det er over 20 AUFere fra Vestfold, noen lett skadd, to skutt $i$ bein. Tett dialog med AUF, som kanskje samler flere berørte og pårørende enn bare dem fra Tønsberg. Det er ekstra traumesykepleier på vakt på legevakten i natt.

\section{Kriseteamet møtes}

Da jeg våknet lørdag morgen, fikk jeg høre på nyhetene at 80 muligens var drept, og at ca. 700 hadde vært til stede på Utøya. Dette ville angå mange kommuner. Jeg kontaktet kommuneoverlegene i nabokommunene og inviterte til utvidet kriseteammøte med kommuneledelsen, med fylkeslegen som observatør. Vi besluttet å etablere kriseteam med base i Arbeiderpartiets lokaler, på ofrenes hjemmebane. Legevakten ble satt i ekstra beredskap. Lister ble gjennomgått, tre savnede, fire skutt, 16 fysisk uskadd. Mange ville trenge noen å snakke med; unge liv i møte med ondskap.

Det vesentlige var å være medmenneske og vise omsorg. Vi snakket med pårørende som ventet på sine savnede på Sundvolden. Dette var samfunnsmedisinsk arbeid med store utfordringer, emosjonelle som faglige.

\section{Facebook natt til søndag}

Det har voert en lang dag som er i ferd med a ta slutt. Nye tøffe tak venter søndag - for å støtte de som trenger å komme sammen og prate, og som trenger profesjonell oppfølging. Atte kommuners kriseteam er fra i morgen slått sammen i ett, som jeg er faglig leder for. Sterke inntrykk i møtet med pårørende og berørte som var på Utøya, og flott samling på Farmannstorvet med mange unge og voksne i går kveld med lysmarkering. Sterkt engasjement og samhold.
Flott og beveget tale av ordfører Petter Berg, engasjerte ungdommer og Kirken. Flott engasjement fra fastleger og fagfolk $i$ spesialisthelsetjenesten, fastboende som ferierende. Snakk sammen, bry dere, gi skulder, øre og hjerte til hverandre. Tål å kjenne den annens smerte, uten å måtte ha løsningene! Vi i kriseteamet er der også for dere i tillegg.

\section{Arbeidet fortsetter}

Informasjon til publikum via pressen var vesentlig, samtidig som sårbare deltakere og pårørende måtte beskyttes. Samarbeidet med Tønsberg Blad fungerte godt. Det var mange henvendelser per telefon. Bistand ble videreformidlet. Helsepersonell med ulik bakgrunn hadde samtaler med pårørende. Deltakere samlet seg med helsepersonell til stede, men det ble bevisst ikke organisert gruppesamtale i akuttfasen. Pårørende ble samlet for å få veiledning om hvordan de skulle forholde seg til ungdommene. Det interkommunale kriseteamet fungerte, og henvendelser ble kanalisert inn i de ordinære helsetjenestene. Pårørende av savnede fikk faste kontaktpersoner, og legevakt og fastleger ble bedt om å rapportere henvendelser slik at kriseteamet hadde oversikt.

\section{Facebook natt til mandag}

Tung tids tale ... Det angår oss alle, men flere av oss er mer rammet enn andre... og da bryr vi oss alle om hverandre og spesielt de som er rammet - ikke sant? De trenger støtte videre. Det er et stort engasjement hos folk $i$ alle aldre, på tvers av yrker, status og politikk.

\section{Debriefing}

Utover i uken var det fakkeltog, nye koordinerende møter, møte med Kirkens ungdomsklubb, minnesmarkering og debriefing av Røde Kors og Sivilforsvarets redningsmannskap. Folkene i Arbeiderpartiet hadde også behov for samtaler. Onsdag kveld var det meste tatt hånd om, og det meste delegert. Paradoksalt nok satt jeg igjen med en tomhetsfølelse. Tankene seg på etter døgnkontinuerlig jobbing på bekostning av ferie og familie.

Torsdag var det debriefing av helsepersonell i samarbeid med psykolog og psykiater ved Psykiatrien i Vestfold. Mange sterke inntrykk. Jeg bestemte meg for selv å delta. Som lege og leder var det en veldig god erfaring å delta selv og lufte tanker.

\section{Tanker i etterkant}

Det er ikke kriseteamets oppgave å kanalisere henvendelser fra mediene. På den annen side er det en belastning for pårørende i dyp sorg å forholde seg til mediene. Det ble derfor opprettet kontaktpersoner for sterkt berørte familier.

Et tankekors er at fastleger ofte må forholde seg til ulykker og suicid. For de det angår, er tapet like smertefullt, kanskje noen ganger verre ved suicid hos unge mennesker. Det er spørsmål og selvbebreidelser. Nå er terrorisme årsaken. Fastleger og spesialisthelsetjeneste anmodes om å ha en lav terskel for bistand. Men er vi gode nok i det daglige? Er terskelen da også lav nok?

Terrorhandlingene stiller også spørsmål ved kommunenes beredskapsordninger. Kommuneoverlegene og kriseteamene forventes å være tilgjengelige, men lønnes ikke for det. 22. juli etter arbeidstid var det umulig å nå flere av kollegene og kriseteam. Det var også tilfeldig at jeg var tilgjengelig. Beredskapsordningene bør drøftes.

Det var en positiv opplevelse å ha stort overskudd på leger og annet helsepersonell. Mange følte nok avmakt ved ikke å kunne hjelpe, andre tilfredsstillelse ved å bistå i en dypt tragisk hendelse. Mange vil trenge hverandre som gode medmennesker videre når mediene har stilnet. Noen vil også trenge god profesjonell oppfølging.

\section{Frank Thrana}

frank.thrana@tonsberg.kommune.no Tønsberg kommune

Frank Thrana (f. 1961) er kommuneoverlege

i Tønsberg kommune.

Ingen oppgitte interessekonflikter.

Mottatt 30.8. 2011 og godkjent 30.8. 2011.

Medisinsk redaktør Erlend Hem.

Engelsk oversettelse av hele artikkelen på www.tidsskriftet.no 